\title{
A Green Protocol for Synthesis of Some Novel 3-(2-Chloroquinolin-3-yl)acrylic Acid via Knoevenagal Reaction
}

\author{
R. A. SHASTRI* and P. P. JOSHI \\ Post Graduate Department of Chemistry, \\ SBES College of Science, Aurangabad- 431001 (Maharashtra), India \\ shastriranjana@yahoo.com
}

Received 22 June 2014 / Accepted 26 July 2014

\begin{abstract}
A series of novel 3-(2-chloroquinolin -3- yl)acrylic acid derivatives (3a-j) were prepared by Knoevenagal condensation of 2-chloro 3-formyl quinoline (2a-j) with malonic acid (2) in the presence of catalytic quantity of pyridine under microwave irradiation in excellent yield with short time span (70 s). Newly synthesized compounds were characterized by IR, ${ }^{1} \mathrm{H}$ NMR and mass.
\end{abstract}

Keywords: 2-Chloro-3-formyl quinoline, Malonic acid, Pyridine, Acrylic acid, Microwave

\section{Introduction}

The growing interest in quinoline and its derivatives are not only due to anti-malarial, antibacterial, antiviral, antifungal, antiasthamatic, antihypertensive, analgesic and antiinflammatory, but also cytotoxic, anti-platelet, antiprion, $\mathrm{H}+/ \mathrm{K}+$ ATPase inhibitor, leukotrien biosynthesis inhibitor activity ${ }^{1-5}$. Quinaldic acid is carbolic acid, substituted quinoline at 2 position is a catabolite of tryptophan aromatic side chain amino acid. It is a fundamental peripheral vasodilator. Interesting pharmacological properties have been associated with 2-chloroquinoline-3-carbaldehydes and their derivatives ${ }^{6-7}$. These compounds have shown antimicrobial $^{6-8}$, antimalarial ${ }^{9-10}$, anti-inflammatory ${ }^{11-14}$, antitumor ${ }^{15,16}$ and antiparasitic activity $^{17}$. Derivatives of 3-(quinolin-3-yl)acrylates and the corresponding reduced allylic alcohols that have been identified by Bristol-Myers Squibb (BMS) as novel and potent maxi-K channel openers useful for the treatment of male erectile dysfunction ${ }^{18}$.

Due to such a wide range of applicability in medicinal field, there is increasing interest in the development of efficient methodologies for the synthesis of quinoline derivatives. The main objective of the present investigation is to provide the synthesis of some novel substituted 3-(2-chloroquinolin-3-yl)acrylic acid.

The Knoevenagel condensation is one of the most effective synthetic method for the synthesis of several important key products that include unsaturated acids and unsaturated ester intermediates employed in the synthesis of several therapeutic drugs (e.g. Niphendipine 
and nitrendipine) and pharmacological products (e.g. calcium channel blockers and antihypertensive). In general the reaction is carried by the condensation of carbonyl compounds with active methylenes in the presence of base by conventional heating which requires prolonged reaction time. In order to shorten reaction time and ease of manipulation of Knoevenagel condensation microwave irradiation condition have been adopted.

Moreover microwave assisted reaction have attracted much interest because of simplicity in operation, greater selectivity and rapid synthesis of certain unsuccessful or low yielding reactions, reducing the reaction time from hours to minutes in a variety of heterocyclic compounds. In view of these observations and in continuation of our earlier work on the synthesis of 2-chloro-3-formylquinoline derivative ${ }^{19}$, we herein report the synthesis of 3-(2-chloroquinolin-3-yl)acrylic acids.

The general synthetic pathway discussed hereafter is depicted in Scheme 1. The starting compounds 2-chloro-3-formyl quinoline dervatives (1a-j) were prepared by Vilsmeier Haack reaction according to literature method ${ }^{20}$. Compound (1) on treatment with malonic acid (2) in the presence of pyridine as base yielded 3-(2-chloroquinolin-3-yl)acrylic acid derivatives (3a-j). The purity of synthesized compounds is checked by TLC (ethyl acetate: benzene). All synthesized compounds (3a-j) were characterized by IR, ${ }^{1} \mathrm{H}$ NMR and Mass spectrometric techniques Table 1 .

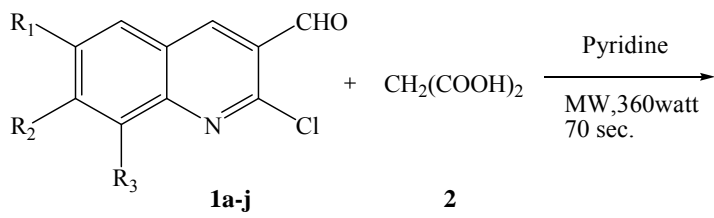<smiles>[R]c1cc2cc(/C=C/C(=O)O)c(Cl)nc2c([R3])c1[R]</smiles>

\section{Scheme 1}

\section{Experimental}

All melting points were determined in open capillary tubes and are uncorrected. The homogeneity of all the compounds were checked by TLC on silica gel coated plates. IR spectra were obtained in $\mathrm{KBr}$ on Perkin-Elmer FTIR Spectrophotometer. ${ }^{1} \mathrm{H}$ NMR spectra were recorded in $\mathrm{CDCl}_{3}$ on varian NMR spectrometer operating at $400 \mathrm{MHz}$. Chemical Shifts are expressed in $\delta$ w.r.t. TMS. Mass spectra were recorded on a MICRO MASS operating at $70 \mathrm{eV}$. Analytical Thin Layer Chromatography was performed with E Merck precoated TLC plates, silica gel $60 \mathrm{~F}_{254}$ layer thickness 0.25 $\mathrm{mm}$. Microwave irradiation was carried out in a microwave oven (LG, $800 \mathrm{~T}, 2450 \mathrm{MHz})$ with power output of 360 watt.

\section{General procedure for the synthesis of 3-(2-chloroquinolin-3-yl)acrylic acid (3a)}

A mixture of substituted 2-chloro-3-formyl quinoline $(0.204 \mathrm{~g}, 1.0 \mathrm{mmol})$ and malonic acid $(0.208,2 \mathrm{mmol})$ in catalytic amount of pyridine $(2-3 \mathrm{~mL})$ was irradiated in microwave oven at 360 watt for 60-70 s Stirred with an interval of $5 \mathrm{~s}$ with intermittent cooling. The reaction mixture was poured immediately in ice-cold water and stirred continuously. The separated solid was filtered and dissolved in sodium bicarbonate and re-precipitated by dilute hydrochloric acid at neutral $\mathrm{pH}$. The separated solid was filtered and recrystallised from aq. ethanol to give compounds 3a. Similarly, compounds 3b-j were prepared. Physical data of substituted 3-(2-chloroquinolin-3-yl)acrylic acids are given in Table 1. 
Table 1. Physical data of compounds 3a-j

\begin{tabular}{ccccccc}
\hline Compounds & $\mathrm{R}_{1}$ & $\mathrm{R}_{2}$ & $\mathrm{R}_{3}$ & M.P ${ }^{\circ} \mathrm{C}$ & $\begin{array}{c}\text { Yield, } \\
\%\end{array}$ & $\begin{array}{c}\text { Time, } \\
\text { s }\end{array}$ \\
\hline 3a & $\mathrm{H}$ & $\mathrm{H}$ & $\mathrm{CH}_{3}$ & 258 & 95 & 70 \\
3b & $\mathrm{H}$ & $\mathrm{Br}$ & $\mathrm{CH}_{3}$ & 262 & 90 & 70 \\
3c & $\mathrm{H}$ & $\mathrm{CH}_{3}$ & $\mathrm{H}$ & 168 & 80 & 70 \\
3d & $\mathrm{NO}_{2}$ & $\mathrm{CH}_{3}$ & $\mathrm{H}$ & 280 & 80 & 70 \\
3e & $\mathrm{OCH}_{3}$ & $\mathrm{H}$ & $\mathrm{H}$ & 122 & 75 & 70 \\
3f & $\mathrm{Br}$ & $\mathrm{CH}_{3}$ & $\mathrm{H}$ & 286 & 80 & 70 \\
3g & $\mathrm{H}$ & $\mathrm{H}$ & $\mathrm{Cl}$ & 124 & 75 & 70 \\
3h & $\mathrm{Br}$ & $\mathrm{CH}_{3}$ & $\mathrm{NO}_{2}$ & 248 & 70 & 70 \\
3i & $\mathrm{CH}_{3}$ & $\mathrm{NO}_{2}$ & $\mathrm{H}$ & $>300$ & 82 & 70 \\
3j & $\mathrm{CH}_{3}$ & $\mathrm{H}$ & $\mathrm{H}$ & $>300$ & 70 & 70 \\
\hline
\end{tabular}

\section{Spectral data}

8-Methyl-3-(2-chloroquinolin-3-yl)acrylic acid (3a)

${ }^{1} \mathrm{H}$ NMR (400MHz, DMSO): $\delta 11.01(\mathrm{~s}, 1 \mathrm{H}, \mathrm{COOH}), 7.60\left(\mathrm{~d}, 1 \mathrm{H}, 16 \mathrm{~Hz}, \mathrm{CH}_{\mathrm{A}}=\right), 7.02(\mathrm{~d}, 1 \mathrm{H}$, $\left.16 \mathrm{~Hz},=\mathrm{CH}_{\mathrm{B}}\right), 8.28\left(\mathrm{~s}, 1 \mathrm{H}, \mathrm{C}_{4}-\mathrm{H}\right), 7.91(\mathrm{~m}, 3 \mathrm{H}, \mathrm{Ar}-\mathrm{H}), 2.44\left(\mathrm{~s}, 3 \mathrm{H}, \mathrm{CH}_{3}\right) \mathrm{IR}\left(\mathrm{KBr} \mathrm{cm}^{-1}\right): 3250-$ $2500(\mathrm{OH}$ of $\mathrm{COOH}), 1690(\mathrm{C}=\mathrm{O}) 1610(\mathrm{C}=\mathrm{C}) \cdot \mathrm{MS} \mathrm{m} / \mathrm{z} 247(\mathrm{M}+)$.

8-Methyl-7-bromo-3-(2-chloroquinolin-3-yl)acrylic acid (3b)

${ }^{1} \mathrm{H}$ NMR (400MHz, DMSO): $\delta 11.02(\mathrm{~s}, 1 \mathrm{H}, \mathrm{COOH}), 7.98-7.94\left(\mathrm{~d}, 1 \mathrm{H}, 16 \mathrm{~Hz}, \mathrm{CH}_{\mathrm{A}}=\right), 6.73-6.69$ $\left(\mathrm{d}, 1 \mathrm{H}, 16 \mathrm{~Hz},=\mathrm{CH}_{\mathrm{B}}\right), 8.79\left(\mathrm{~s}, 1 \mathrm{H}, \mathrm{C}_{4}-\mathrm{H}\right), 7.85-7.67(\mathrm{~m}, 2 \mathrm{H}, \mathrm{Ar}-\mathrm{H}), 2.42\left(\mathrm{~s}, 3 \mathrm{H}, \mathrm{CH}_{3}\right) . \mathrm{IR}\left(\mathrm{KBr} \mathrm{cm}^{-1}\right)$ : 3250-2500 (OH of $\mathrm{COOH}), 1685(\mathrm{C}=\mathrm{O}), 1609(\mathrm{C}=\mathrm{C}) \cdot \mathrm{MS} \mathrm{m} / \mathrm{z} 325(\mathrm{M}+), 327(\mathrm{M}+2)$.

7-Methyl-3-(2-chloroquinolin-3-yl)acrylic acid (3c)

${ }^{1} \mathrm{H}$ NMR (400MHz, DMSO): $\delta 11.01(\mathrm{~s}, 1 \mathrm{H}, \mathrm{COOH}), 7.60-7.56\left(\mathrm{~d}, 1 \mathrm{H}, 16 \mathrm{~Hz}, \mathrm{CH}_{\mathrm{A}}=\right), 7.66-$ $7.02\left(\mathrm{~d}, 1 \mathrm{H}, 16 \mathrm{~Hz},=\mathrm{CH}_{\mathrm{B}}\right), 8.38\left(\mathrm{~s}, 1 \mathrm{H}, \mathrm{C}_{4}-\mathrm{H}\right), 7.90(\mathrm{~m}, 3 \mathrm{H}, \mathrm{Ar}-\mathrm{H}), 2.40\left(\mathrm{~s}, 3 \mathrm{H}, \mathrm{CH}_{3}\right) \mathrm{IR}(\mathrm{KBr}$ $\left.\mathrm{cm}^{-1}\right): 3250-2500(\mathrm{OH}$ of $\mathrm{COOH}), 1685(\mathrm{C}=\mathrm{O}), 1607(\mathrm{C}=\mathrm{C}) . \mathrm{MS} \mathrm{m} / \mathrm{z} 247(\mathrm{M}+)$.

7-Methyl 6-nitro-3-(2-chloroquinolin-3-yl) acrylic acid (3d)

${ }^{1} \mathrm{H}$ NMR (400MHz, DMSO): $\delta 13.3(\mathrm{~s}, 1 \mathrm{H}, \mathrm{COOH}), 8.12-8.10\left(\mathrm{~d}, 1 \mathrm{H}, 16 \mathrm{~Hz}, \mathrm{CH}_{\mathrm{A}}=\right), 7.40-$ $7.38\left(\mathrm{~d}, 1 \mathrm{H}, 16 \mathrm{~Hz},=\mathrm{CH}_{\mathrm{B}}\right), 9.04\left(\mathrm{~s}, 1 \mathrm{H}, \mathrm{C}_{4}-\mathrm{H}\right), 7.3-7.9(\mathrm{~m}, 3 \mathrm{H}, \mathrm{Ar}-\mathrm{H}), 3.91\left(\mathrm{~s}, 3 \mathrm{H}, \mathrm{OCH}_{3}\right) . \mathrm{IR}$ $\left(\mathrm{KBr} \mathrm{cm}^{-1}\right)$ : 3300-2500 (OH of $\left.\mathrm{COOH}\right), 1687(\mathrm{C}=\mathrm{O}), 1605(\mathrm{C}=\mathrm{C}) \cdot \mathrm{MS} \mathrm{m} / \mathrm{z} 292(\mathrm{M}+)$.

6-Methoxy-3-(2-chloroquinolin-3-yl) acrylic acid (3e)

${ }^{1} \mathrm{H}$ NMR (400MHz, DMSO): $\delta 11.61(\mathrm{~s}, 1 \mathrm{H}, \mathrm{COOH}), 7.84-7.82\left(\mathrm{~d}, 1 \mathrm{H}, 8 \mathrm{~Hz}, \mathrm{CH}_{\mathrm{A}}=\right), 7.36-7.34$ $\left(\mathrm{d}, 1 \mathrm{H}, 8 \mathrm{~Hz},=\mathrm{CH}_{\mathrm{B}}\right), 8.78\left(\mathrm{~s}, 1 \mathrm{H}, \mathrm{C}_{4}-\mathrm{H}\right), 8.80\left(\mathrm{~s}, 1 \mathrm{H}, \mathrm{C}_{5}-\mathrm{H}\right), 7.42\left(\mathrm{~s}, 1 \mathrm{H}, \mathrm{C}_{8}-\mathrm{H}\right), 2.78\left(\mathrm{~s}, 3 \mathrm{H}, \mathrm{CH}_{3}\right)$. IR $\left(\mathrm{KBr} \mathrm{cm}^{-1}\right)$ : 3300-2500 (OH of $\left.\mathrm{COOH}\right), 1690(\mathrm{C}=\mathrm{O}), 1605(\mathrm{C}=\mathrm{C}) . \mathrm{MS} \mathrm{m} / \mathrm{z} 263(\mathrm{M}+)$.

7-Methyl 6-bromo-3-(2-chloroquinolin-3-yl) acrylic acid (3f)

${ }^{1} \mathrm{H}$ NMR (400MHz, DMSO): $\delta 12.03(\mathrm{~s}, 1 \mathrm{H}, \mathrm{COOH}), 7.60-7.56\left(\mathrm{~d}, 1 \mathrm{H}, 16 \mathrm{~Hz}, \mathrm{CH}_{\mathrm{A}}=\right), 7.01-$ $6.97\left(\mathrm{~d}, 1 \mathrm{H}, 16 \mathrm{~Hz},=\mathrm{CH}_{\mathrm{B}}\right), 8.23\left(\mathrm{~s}, 1 \mathrm{H}, \mathrm{C}_{4}-\mathrm{H}\right), 7.91\left(\mathrm{~s}, 1 \mathrm{H}, \mathrm{C}_{5}-\mathrm{H}\right) \quad 7.25\left(\mathrm{~s}, 1 \mathrm{H}, \mathrm{C}_{8}-\mathrm{H}\right)$, 2.44(s,3H, $\left.\mathrm{CH}_{3}\right)$ IR $\left(\mathrm{KBr} \mathrm{cm}^{-1}\right): 3250-2500(\mathrm{OH}$ of $\mathrm{COOH}), 1685(\mathrm{C}=\mathrm{O}), 1605(\mathrm{C}=\mathrm{C}) . \mathrm{MS}$ $\mathrm{m} / \mathrm{z} 325(\mathrm{M}+), 327(\mathrm{M}+2)$.

8-Chloro-3-(2-chloroquinolin-3-yl) acrylic acid (3g)

${ }^{1} \mathrm{H}$ NMR $\left(400 \mathrm{MHz}, \mathrm{CDCl}_{3}\right): \delta 12.4(\mathrm{~s}, 1 \mathrm{H}, \mathrm{COOH}), 8.14-8.12\left(\mathrm{~d}, 1 \mathrm{H}, 8 \mathrm{~Hz}, \mathrm{CH}_{\mathrm{A}}=\right), 8.12-8.10$ $\left(\mathrm{d}, 1 \mathrm{H}, 8 \mathrm{~Hz}, \mathrm{CH}_{\mathrm{B}}=\right), 7.6-7.2(\mathrm{~m}, 4 \mathrm{H}, \mathrm{Ar}-\mathrm{H}) 7.02\left(\mathrm{~d}, 1 \mathrm{H},=\mathrm{CH}_{\mathrm{B}}\right), 7.6-7.2(\mathrm{~m}, 4 \mathrm{H}, \mathrm{Ar}-\mathrm{H}) . \mathrm{IR}(\mathrm{KBr}$ $\left.\mathrm{cm}^{-1}\right)$ : 3250-2560 (OH of COOH), $1687(\mathrm{C}=\mathrm{O}), 1602(\mathrm{C}=\mathrm{C}) \cdot \mathrm{MS} \mathrm{m} / \mathrm{z} 257(\mathrm{M}+)$. 


\section{Results and Discussion}

In continuation of our research interest in microwave assisted synthesis and the development of novel synthetic methodology $y^{21-22}$, herein we report a simple, efficient and rapid synthesis of 3-(2-chloquinoline-3-yl)acrylic acid (Scheme 1).

The aim of the present work is to show that under the microwave irradiation the Knoevenagel condensation can be successfully applied to the synthesis of a number of 3-(2chloroquinolin-3-yl)acrylic acids. It's a very simple, fast and general procedure where the condensation of 2-chloro-3-formyl quinoline or its derivatives with malonic acid in the presence of pyridine under the solvent-free condition leads to 3-(2-chloroquinolin-3yl)acrylic acid Scheme 1.

To evaluate the effect of microwave, we first examined the reaction without microwave at $100{ }^{\circ} \mathrm{C}$ where very low yield $(15-20 \%)$ is obtained with prolonged reaction time (120 min) and by using microwave excellent yield $(70-90 \%)$ is obtained with short reaction time $(70 \mathrm{sec})$. Therefore this method is used to synthesis all acrylic acid derivatives of 2-chloro3-formyl quinoline.

In order to find optimum reaction conditions 2-chloro-3-formyl quinoline was treated with malonic acid in 1:1.5 mole ratio, where less yield was obtained. The same reaction in proportion of 1:2 moles, yielded product in high quantity. In order to study the optimum watt conditions reaction at 800 watt for 40-50 seconds yielded blackish brown product, hence we carried the reaction at 360 watt $\left(110^{\circ} \mathrm{C}\right)$ for $60-70$ seconds which yielded white to pale yellow product in high yield.

A structural evaluation of new derivatives $\mathbf{3 a - j}$ was performed by using various spectroscopic techniques. The IR spectra of these derivatives displayed a band around 3300$2500 \mathrm{~cm}^{-1}$ (OH of $\mathrm{COOH}$ group) and another band at $1615-1600 \mathrm{~cm}^{-1}(\mathrm{CH}=\mathrm{CH})$. A sharp peak at $702 \mathrm{~cm}^{-1}$ was observed for $\mathrm{C}-\mathrm{Cl}$ group. ${ }^{1} \mathrm{H}$ NMR spectra gave signal around $\delta 8.15$ 7.50 (doublet for $\mathrm{CH}_{\mathrm{A}}=$ ), $\delta$ 7.40-6.70 (doublet for $=\mathrm{CH}_{\mathrm{B}}$ ) confirming the presence of ethylenic proton. The proton signal for - $\mathrm{COOH}$ appears in the region $\delta 12.00-11.00$. Further ${ }^{1} \mathrm{H}$ NMR of these compounds shows the absence of singlet in the range $\delta 10.5$ characteristic of aldehydic proton confirms the conversion of aldehyde into unsaturated acid. Further this is supported by chemical test, all the compounds 3a-j were soluble in sodium bicarbonate indicates conversion of aldehyde group into unsaturated acid The mass spectra of these compounds shows molecular ion peaks corresponding to their molecular mass.

\section{Conclusion}

We have developed a new methodology for the synthesis of title compounds. The merits of this method are short reaction time, simple work up procedure and excellent yield of products. To the best of our knowledge this is the first report on the synthesis of 3-(2chloroquinolin-3-yl)acrylic acid

\section{Acknowledgement}

The authors are thankful to the principal Dr. S. V. Birajdar, SBES Science College, Aurangabad, for encouraging during the process of carrying out this work. Thanks are also due to SAIF PU, Chandigarh for the spectral analysis.

\section{References}

1. Korth C, Klingenstein R, Rutger Leliveld S, Melnyk P and Leliveld R, J Med Chem., 2006, 49(17), 5300-5308; .DOI:10.1021/jm0602763 
2. Yum E, Yang O, Kyu Kang S, Cheon H and Kim S, Bull Korean Chem Soc., 2004, 25(7), 1091-1094; DOI:10.5012/bkcs.2004.25.7.1091

3. Deshmukh M, Shelar M and Patils, Indian J Heterocycl Chem., 1997, 6, 181-184.

4. Viahov R, Parushev S and Valhov J, Pure Appl Chem., 1990, 7, 1303-1306.

5. Cheon H, Lim H and Lee D, Eur J Pharm., 2001, 411(1-2), 181-186; DOI:10.1016/S0014-2999(00)00919-5

6. Selvi S T, Nadaraj V, Mohan S, Sasi R and Hema M, Bioorg Med Chem., 2006, 14(11), 3896-3903; DOI:10.1016/j.bmc.2006.01.048

7. Pokalwar R U, Hangarge R V, Maske P V and Shingare M S, Arkivoc, 2006, 11, 196-204.

8. (a) Khidre R E, Abu-Hashem A A and El-Shazly M, Eur J Med Chem., 2011, 46(10), 5057-5064; DOI:10.1016/j.ejmech.2011.08.018; (b) Kidwai M, Saxena S, Khalilur Rahman Khan M and Thukral S S, Eur J Med Chem., 2005, 40(8), 816-819; DOI:10.1016/j.ejmech.2005.02.009

9. Charris J E, Lobo G M, Camacho J, Ferrer R, Barazarte A, Dominguez J N, Gamboa N, Rodrigues J R and Angel J E, Lett Drug Design Discov., 2007, 4(1), 49-54.

10. Kaur K, Jain M, Reddy R P and Jain R, Eur J Med Chem., 2010, 45(8), 3245-3264; DOI:10.1016/j.ejmech.2010.04.011

11. Khidre R E, Abdel-Wahab B F and Badria F A R, Lett Drug Design Discov., 2011, 8(7), 640-648.

12. Chen Y L, Chen I L, Lu C M, Tzeng C C, Tsao L T and Wang J P, Bioorg Med Chem., 2004, 12(2), 387-392; DOI:10.1016/j.bmc.2003.10.051

13. Bawa S and Kumar S, Indian J Chem., 2009, 48B, 142-145.

14. Abdou W M, Khidre R E and Shaddy A A, J Heterocycl Chem., 2013, 50(1), 33-41; DOI:10.1002/jhet.968

15. Abdou W M, Khidre R E and Kamel A A, Arch Pharm Chem Life Sci., 2012, 345(2), 123-136; DOI:10.1002/ardp.201100080

16. (a) Goekjian P G, PCT Int Appl WO 2009090623, (2009); (b) Patin A and Belmont P, Synthesis, 2005, 14, 2400.

17. Kouznetsov V V, Méndez L Y V, Leal S M, Cruz U M, Coronado C A, Gómez C M M, Bohórquez A R R and Rivero P E, Lett Drug Design Discov., 2007, 4, 293.

18. (a) Hewawasam P, Fan W, Ding M, Flint K, Cook D, Goggings G D, Myers R A, Gribkoff V K, Boissard C G, Dworetzky S I, Starret J E and Lodge N J, J Med Chem., 2003, 46(14), 2819-2822; DOI:10.1021/jm030005h; (b) Boy K M, Guernon J M, Sit S Y, Xie K, Hewawasam P, Boissard C G, Dworetzky S I, Natale J, Gribkoff V K, Lodge N and Starret J E, Bioorg Med Chem Lett., 2004, 14(20), 5089-5093; DOI:10.1016/j.bmcl.2004.07.080; (c) Hewawasam P, Fan W, Cook D A, Newberry K S, Boissard C G, Gribkoff V K, Starret J and Lodge N J, Bioorg Med Chem Lett., 2004, 14(17), 4479-4482; DOI:10.1016/j.bmcl.2004.06.051; (d) P Hewawasam W O, Patent 00/34244, 2000

19. Shastri R A, Chem Sci Trans., 2013, 2(3), 883-888; DOI:10.7598/cst2013.457

20. Meth-Cohn O, Narine B and Tarnowski B, J Chem Soc Perkin Trans., 1981, 1, 1520; DOI:10.1039/P19810001520

21. Shastri R A, Pedgaokar S V, Selukara S S and Jadhav S B, J Indian Chem Soc., 2008, 85, 574-576.

22. Shastri R A and Varudkar J S, Indian J Chem., 2009, 48(B), 1156-1160. 